\title{
Macroeconomic Indicators and their Impact on the Foreign Debt Burden: The Case of BRICS Countries
}

\author{
R.G. Akhmadeev ${ }^{1}$, O.A. Bykanova², N.V. Philippova ${ }^{3}$ I.V. Vashchekina ${ }^{4}$, \\ T.B. Turishcheva ${ }^{5}$
}

Abstract:

The main aim of this article is to analyse the macro indicators affecting the foreign debt burden of BRICS.

It has been proven that it is required to design development scenarios in mid-term planning via forming a numerical estimate plane, taking into account expectations of economic variables' behavior and other factors, which would stabilize the debt burden and other indicators at sensible levels.

Using the elimination approach towards the impact of all factors on the amount on the end result except one, the article formulates and proves the hypothesis that market indicators in relation to GDP influence the size of the country's debt.

Keywords: Budget policy, state debt, tax burden on the economy, financial system of the state, macroeconomics, BRICS countries.

JEL Classification: B40; C53; E17; F34.

\footnotetext{
${ }^{1}$ Corresponding author, Ph.D., British Doctor of Philosophy, Associate Professor Department of Accounting and Taxation, Plekhanov Russian University of Economics, ahm_rav@mail.ru

${ }^{2}$ Ph.D., Associate Professor Department of Mathematics, Plekhanov Russian University of Economics, Moscow, Russian Federation

${ }^{3}$ Ph.D., Associate Professor Department of Mathematics, Plekhanov Russian University of Economics, Moscow, Russian Federation

${ }^{4}$ Ph,D., Associate Professor Department of Financial Markets, Plekhanov Russian University of Economics, Moscow, Russian Federation

${ }^{5}$ Ph.D., Associate Professor, Department of Accounting and Taxation, Plekhanov Russian University of Economics, Moscow, Russian Federation, Associate Professor of Department Accounting Financial University under the Government of the Russian Federation
} 


\section{Introduction}

Debt policies have become a pressing problem for the international economy recently causing concerns both in developed and emerging countries because of the uncontrollable growth trend of all types of debt, domestic and foreign, state debt, corporate debt and credit consumer debt. This is why stable conditions for the creation of a necessary level of state guarantees for the national economy are needed since there is no global management guarantor for managing debts. While forming the system of global management, the introduction of a transitory state management system which would formulate the conditions for a significant decrease of debts is needed.

The global economy increases the importance of debt policies and helps cement state guarantees for the national economy, changes the concept of foreign state debt, which cannot longer be regarded the way it was seen in the period of state protectionism, when all types of debt, including state foreign debt, were insignificant. Now, all types of debt are significant while sovereign debt (foreign state debt) demonstrates urgency of the problem.

The vagueness of the 'foreign state debt' concept is acknowledged by researchers, who interpret the economic content of the concept ambiguously. In particular, the issues of reasons behind a detailed consideration of the foreign debt structure, including corporate and state debt, should be discussed in more detail. State debt has a significant and multifaceted role in the process of social and economic development of any country. This is because state management bodies' decisions related to forming, servicing and redempting the liabilities have a strong impact on government finances, currency circulation, investment climate, consumption structure and the development of international cooperation.

The reason of state debt appearance roots in the government's internal and foreign policy, which fails to provide a balanced budget. At the same time, we cannot single out a country, which has never encountered the problem at one time or another in its history. State debt is an inseparable part of most financial systems. In particular, borrowing policies to finance budget spending is widely used in international practice. Consequently, state debt is a normal phenomenon in the economy of any civilized open to trade country.

From the economic point of view, state debt or sovereign debt, is the debt of the government, which appears as a result of forming additional financial obligations of a country allocated, among others, to solve contradictions between economic and social needs of the society through borrowing funds from households, government institutions, foreign states and international financial entities. From the practical point of view, state debt or sovereign debt represents total unredeemed liabilities of a country against creditors. 


\section{Concept Definitions}

Various theoretical approaches to assess the state debt role are used in academic literature. By raising additional financial resources through increasing debt the government creates new possibilities for economic growth closing the development gap with developed states, however it creates sovereign debt. Budget deficit financing with the help of boosting state debt is a realistic alternative to the tax burden. At that, debt financing has a lesser political price compared with tax increases. State debt can perform the role of a financial mechanism, which speeds up economic development by replacing tax payments. At the same time, foreign state debt represents borrowings raised mostly from foreign governments (legal entities and international associations), from which state financial liabilities making part of a global government debt system, arise.

At that, the government by its status is a party representing a borrower or a debtor. In its turn, the state gets money from taxpayers when collecting taxes while at the same time borrows money to finance the government budget. The tax revenue of the government is its "domestic debt" which it repays in the form of budget spending to support and develop the social system of the country, including public education, public healthcare, science, defense, social security, pensions, etc.

This means that foreign state borrowing can only be justified by budget deficits, when budget spending does not cover the needs of the social security protection. Consequently, the economy is able of liquidating budget deficits, helping the government to avoid foreign borrowing through an additional monetary emission, budget spending reduction, tax and payments increases, widening the subject of taxation (sales revenue, income, net profit, property, etc.). At the same time, the choice of such instruments is controversial from the point of view of regulating the size of government foreign debt. In particular, economic discussions have been held since the time of John Keynes, who believed that the fiscal policy of a state, which creates the possibility of credits to the government through tax borrowing a powerful instrument of national economy management, demand stimulation (Avramovic, 1964). His scientific works point to the possibility of accumulating domestic state debt to provide high budget spending while his theory did not mention the issue of foreign state debt on purpose. According to John Keynes, the government can resort to foreign borrowing for the sake of supporting budget spending, but this task is also equal to a skillful fiscal policy. By pursuing a skillful fiscal policy of raising/lowering taxes depending on the overheat (recession) of the national economy, the government thus manages its domestic debt, which in this way does not require any special attention, is not a current macroeconomic variable, the same as foreign state debt.

Mankiw considered the choice of corresponding instruments to form the optimal budget and taxation policy from the point of view of the national economy growth (Reinhart and Rogoff, 2004). He singled out two types of economic subjects' 
behavior - a 'saving' behavior and a 'spending' behavior. At that, tax reduction by the government at the expense of state debt growth leads to capital spending in the short term. At the same time, a higher economic activity is compensated by the very system of 'spending' economy in the long-term, i.e., the size of state debt is an insignificant macroeconomic factor in a 'spending' economy (Vashchekin, 2005).

Thus, the state debt, being a significant macroeconomic variable, is capable of exerting influence on the economy. For this, it takes abandoning the system of 'spending' economy, where highly profitable 'saving' economic subjects cannot find a use for themselves as economic growth agents, since they only have a stabilizing function in relation to capital size fluctuations. But state debt inevitably acquires great significance in a 'spending' economy, because it is not compensated or poorly compensated by growth. Consequently, the very existence of a large state debt testifies to the fact that the economy with such a burden experiences ample problems of implementing its long-term growth possibilities regardless of the type (spending or saving). Such a conclusion is confirmed by works of Nobel Economics Laureate Paul Samuelson (Cerra et al., 2008). A large amount of state debt has a negative impact on the efficiency of economic activities, leads to shrinking consumption because of the need to service foreign debt and reduces the country's economic growth potential through replacement of private capital and forcing the government to raise taxes.

\section{Research Methodology}

In our research, we, via structuring and systematizing statistical information with the help of the key methods of statistical analysis, we will analyze the impact of a state debt to corporate debt ratio among the countries constituting the group of BRICS. It is important to note that the financial quarterly foreign debt data of the World Bank for the period of 2015-2016 by the general government, Central Bank deposit-taking corporations (except the Central Bank), other sectors, were taken as the basis.

We should note the importance for a scientific research of the ratio between the debt burden as a share of the government sector over the corporate sector under the formula (1):

$X_{i}^{k}=\frac{a_{i}^{k}}{b_{i}^{k}}$

where $a_{i}^{k}$ is the sum of state debt, including general government and Central Bank; $\mathrm{b}_{\mathrm{i}}^{\mathrm{k}}$ is the sum of corporate debt, including deposit-taking corporations, except the Central Bank;

$\mathrm{i}$ is the number of included quarters of a corresponding year from 2015Q1 to 2016Q3; $\mathrm{k}$ is the number of a country from BRICS (1- China, 2 - Brasil, 3 - India, 4 - Russia, 5 - South Africa). 
The calculated empirical data with the use of formula (1) is reflected in Table 1 by country. When using the correlation analysis method, which allows us to assess the character and scale of interrelation between the chosen characteristics, the simple linear Pearson correlation was chosen as a measure of interrelation between the series (Arrow, 1974). The $\mathrm{x}$ and $\mathrm{y}$ relation is linear, if a straight line drawn through the central part of a cluster of points produces the best approximation of the correlation.

Table 1. The share of the ratio of state debt to corporate debt in BRICS countries

\begin{tabular}{llllll}
\hline Period Quarter & China & Brasil & India & Russia & South Africa \\
\hline 2015Q1 & 0,11 & 0,78 & 0,23 & 0,18 & 0,80 \\
2015Q2 & 0,11 & 0,82 & 0,23 & 0,20 & 0,83 \\
2015Q3 & 0,12 & 0,67 & 0,23 & 0,18 & 0,78 \\
2015Q4 & 0,15 & 0,70 & 0,23 & 0,18 & 0,68 \\
2016Q1 & 0,20 & 0,73 & 0,24 & 0,19 & 0,76 \\
2016Q2 & 0,20 & 0,79 & 0,25 & 0,21 & 0,84 \\
2016Q3 & 0,19 & 0,77 & 0,25 & 0,25 & 0,88 \\
\hline
\end{tabular}

It is noted that the determination coefficient of paired regression coincides with the square of the correlation coefficient $r$ (for linear regression). In its turn, the assessment of the quality of the mathematic model (the function equation) shows the value of the determination coefficient for the linear regression, or a square of the correlation index $\rho_{\mathrm{xy}}^{2}=\sqrt{1-\frac{\sigma_{\mathrm{ocr}}^{2}}{\sigma_{\mathrm{y}}^{2}}}$ for the nonlinear regression. Analysis of correlation dependence of the share of state debt to corporate debt in BRICS countries was done by constructing a matrix of the correlation coefficients for the research period (Table 2).

Table 2. The correlation matrix in BRICS countries

\begin{tabular}{|c|c|c|c|c|c|}
\hline BRICS members & China & Brasil & India & Russia & South Africa \\
\hline China & 1 & & & & \\
\hline Brasil & 0,03249 & 1 & & & \\
\hline India & 0,819784 & 0,310494 & 1 & & \\
\hline Russia & 0,597053 & 0,409482 & 0,866702 & 1 & \\
\hline South Africa & 0,179119 & 0,663387 & 0,533799 & 0,752999 & 1 \\
\hline
\end{tabular}

Based on the correlation data from Table 2 we can formulate the following statement. There is a general trend for all BRICS countries state debt to corporate ratios and the presence for them of general links in the parameters under study, because the most part of the correlation coefficients between the figures is above 0.5 in absolute terms. At that, we should single out one country, The People's Republic of China, because its correlation coefficients with the countries of Brazil and South Africa are close to 0 , which allows us to come to a conclusion of its independent state debt management policy. The following step is aimed at creating a mid-term 
forecast for the BRICS countries based on the econometric equations of each country as presented in the next section (Figure 3).

Figure 3. The forecast of dynamics foreign debt changes for BRICS

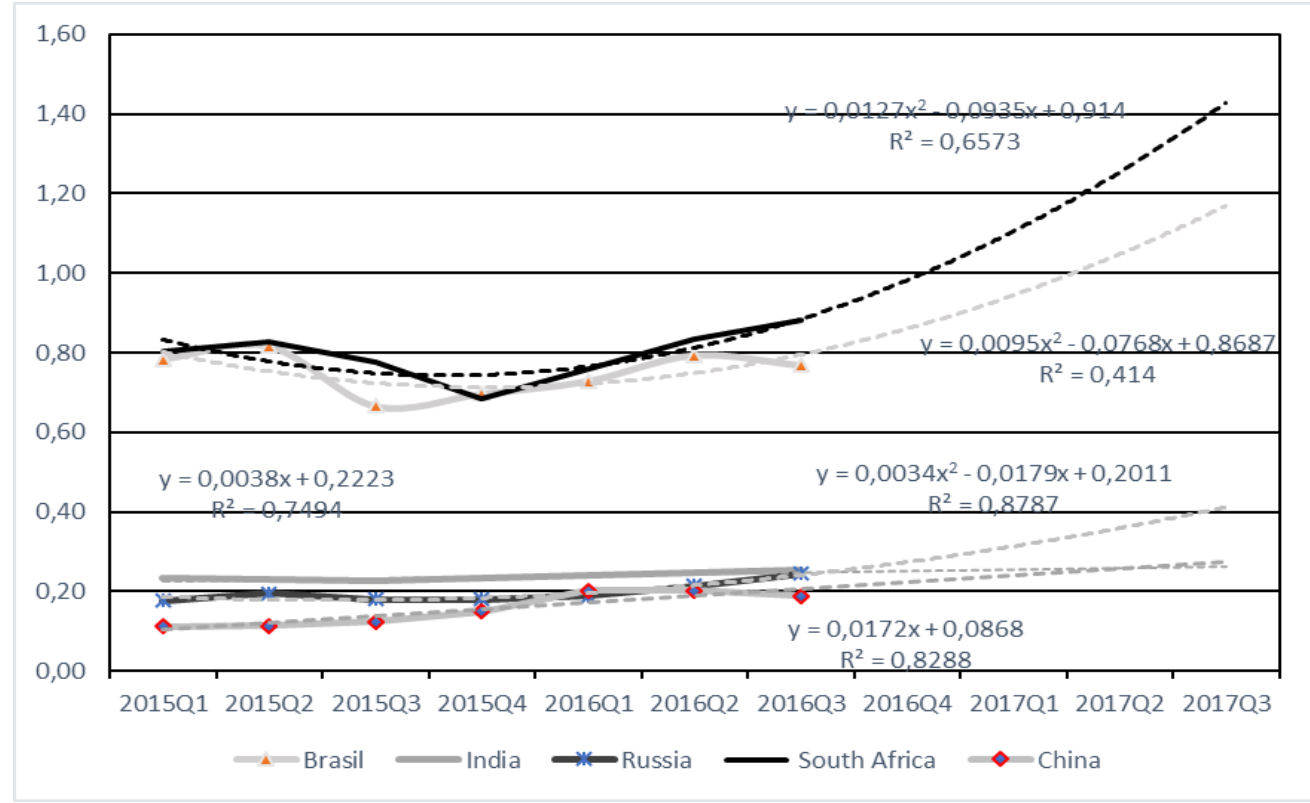

We should note that while determining correlation between the numeric parameters of foreign debt sizes among BRICS we have formulated the following statements:

a) BRICS have demonstrated a sustainable trend raising the state debt share in the overall volume of foreign debt based on the forecast in the third quarter of 2017;

b) A fall of the corporate debt share in the overall amount of foreign debt at quite a speed is typical in Brazil and South Africa. This is an additional proof of a higher state control over the foreign debt structure trend;

c) India, China and Russia continue to increase the share of state debt in total foreign debt at a moderate speed.

\section{Research Hypotheses}

The international macroeconomic policy theory for overcoming crises in the last few decades states the notion of viable debt - the size of the debt, which allows the debtor country to meet its current and future debt liabilities fully, without turning for a further debt relief or restructuring, without accumulation of excessive volumes of debt. At that, economic growth of the country is at an acceptable level. Sticking to mid-term planning of development scenarios is of utmost importance in our research of characteristics and degree of foreign debt burden influence on a country's economy. The approach to such a scenario is formulated in the plane of numerical 
estimates, which take expectations of economic variables and other factors into consideration to determine conditions at which the debt burden and other indicators would stabilize at acceptable levels. The following statement express the aim and the scope of this research:

$\checkmark$ market indicators' ratio to the country's GDP influence the ratio of state debt to GDP.

We have undertaken the assessment of factors, which exclude the influence on the value of the end figure, except one, with the help of variance analysis, and it allowed us to formulate the following hypothesis:

$\checkmark$ the scope of the discovered factors' influence on the change of dependence of foreign debt to a country's GDP is approved.

To reveal the degree of influence of the factors we used the equation of linear multiple regression (5), defined by the following functional dependence:

$y_{k}=\beta_{0 k}+\beta_{1 k} x_{1}+\beta_{2 k} x_{2}+\beta_{3 k} x_{3}+\beta_{4 k} x_{4}+\beta_{5 k} x_{5}+\varepsilon_{k}$

where $y_{k}-$ the state debt to GDP ratio;

$\mathrm{x}_{1}$ - industrial production growth rates;

$\mathrm{x}_{2}$ - the ratio of exports to GDP;

$\mathrm{x}_{3}-$ the ratio of imports to GDP;

$\mathrm{x}_{4}$ - inflation rate;

$\mathrm{x}_{5}$ - unemployment;

$\beta_{\mathrm{ik}}$ - unknown parameters;

$\varepsilon_{\mathrm{k}}$ - random disturbances (deviation of theoretical values from practical values);

$\mathrm{i}=\overline{0,5}, \mathrm{k}=\overline{1,5}$ (the BRICS states: China, India, Brazil, Russia, and South Africa).

It should be noted that the problem of endogeneity of unknown variables can arise, which characterizes the reverse effect of economic indicators, which does not exclude the assertion about the level of their mutual influence. The basic data to confirm our hypothesis are in Appendix A. The empirical ratio data we have received on the correlations, which satisfy the linear regression equation for each state, which comprises the BRICS for the period of 2006-2015, are reflected in Appendix B. Based on the processed data on dependence of state debt on industrial production growth, the ratio of exports to GDP, the ratio of imports to GDP, the inflation rate in the country, the unemployment rate in the country for each country in the group of BRICS is characterized by a linear equation as follows:

$\mathrm{y}_{1}=7,83-0,31 \mathrm{x}_{1}-174,8 \mathrm{x}_{2}+280,94 \mathrm{x}_{3}+2,99 \mathrm{x}_{4}-1,06 \mathrm{x}_{5}$ for China;

$\mathrm{y}_{2}=32,57-0,64 \mathrm{x}_{1}-116 \mathrm{x}_{2}+151,02 \mathrm{x}_{3}+0,42 \mathrm{x}_{4}+3,74 \mathrm{x}_{5}$ for Brazil;

$\mathrm{y}_{3}=100,4-0,86 \mathrm{x}_{1}-760,33 \mathrm{x}_{2}+337,93 \mathrm{x}_{3}+1,76 \mathrm{x}_{4}-2,2 \mathrm{x}_{5}$ for India; 
$\mathrm{y}_{4}=11,85-0,12 \mathrm{x}_{1}+77,78 \mathrm{x}_{2}-146,39 \mathrm{x}_{3}+0,24 \mathrm{x}_{4}-0,19 \mathrm{x}_{5}$ for Russia;

$y_{5}=13,81-0,11 x_{1}-264,29 x_{2}+350,73 x_{3}-3,21 x_{4}+0,79 x_{5}$ for South Africa.

The descriptive characteristics of functional dependence in the equations are characterized by qualitative changes in the countries of Brazil and South Africa. The dependence we have studied between the variable (the size of state debt as related to the size of GDP of a country) and the influence on it of other factors. The values of the coefficient of determination is high and $\mathrm{F}$ - statistic (a critical value of Fisher distribution amounted to 5,11 and this is a lesser value compared with values of other factors we received in our calculations) point to this. For the countries of Russia, India and China the equations of descriptive characteristics of functional relationship can be considered insignificant from the point of view of consistent description of dependence on the influence of the factors under consideration.

Thus, we can formulate the following proof of our hypothesis. The factor of industrial production growth rate influences the size of state debt in all BRICS, consequently, when industrial production grows in a country, foreign debt falls, because of stable negative values of coefficient $\beta_{1 \mathrm{k}}$ on the countries under research. A further check of significance of the linear multiple regression coefficients we have received on the basis of $t-S t a t i s t i c$ and P-value ( $t$ Statistic parameters define the coefficients as significant, parameters P-value do not exceed 0.05 also point to significance of the variables) demonstrated the following results. The most significant factors, which influence the size of state debt for China is the volume of exports, for Brazil is the production output growth and the unemployment rate, for India and Russia is the production output growth, while for South Africa is the level of unemployment (Table 4).

Table 4. The final values of the regressive analysis by country

\begin{tabular}{llll}
\hline BRICS members & Regression Statistics & R Squared & F \\
\hline China & $y_{1}=-20,56+212,3 x_{3}$ & 0.541627 & 8.271394 \\
India & $y_{3}=95,15-250,55 x_{1}$ & 0.443276 & 5.573551 \\
Brasil & $y_{2}=44,79-0,72 x_{1}+2,59 x_{5}$ & 0.903317 & 28.02916 \\
Russia & $y_{4}=9,53-0,2 x_{1}$ & 0.437252 & 5.438962 \\
South Africa & $\mathrm{y}_{5}=-10038+5,64 \mathrm{x}_{5}$ & 0.724494 & 18.40783 \\
\hline
\end{tabular}

Thus, the regressive and variance analyses of financial indicators' ratios for the BRICS we have undertaken allowed us to reveal two market indicators which have a significant influence on the size of state debt. The industrial production growth and the unemployment rate in the country. The research we have undertaken allowed us to formulate the following statements: 
a) for all the countries of BRICS' group the assumption of direct influence of industrial production growth on state debt size was proved - industrial production growth entails a falling state debt. The factor is most significant for Russia and India compared with the other factors (the values of $t$ Statistics vary from -2.4 and -2.3 consequently, $\mathrm{P}$-value is 0.05 );

b) for Brazil and South Africa the assumption of significance of the unemployment rate from the point of view of its influence on the state debt size was proved. This parameter is more significant for South Africa than other factors (t Statistic values amounted to 4.3 , while $\mathrm{P}$-value is 0.004 );

c) for China import volumes is the most significant factor (when assessing the impact of individual parameters), which is proved by the value of t Statistic amounted to 2.9 , while $\mathrm{P}$-value is 0,02 .

\section{Discussion}

Different macroeconomic indicators can be used, when compiling foreign debt stabilization programmers as economic guidance in the budget policy of international countries. Based on the present research one should take into account the influence of various factors, which have an impact on the characteristics and the structure of foreign debt as well as ways and methods of its management via:

a) the order of use when forming the budget deficit volume of a country with selected criteria of its balance, investment spending, etc.;

b) sticking to parity of budget revenues and spending taking into account the cap on the budget deficit depending of its ratio with GDP, structuring income and spending issues of the budget at all levels;

c) the equality of the size of state borrowing and capital investment in accordance with the 'golden rule' principle for the current account;

d) setting the boundaries of gross and net state debt by limiting the ratio of total (net) liabilities to GDP, forming a certain volume of money to be put into nonbudget reserve funds, as well as setting the upper foreign debt limit in absolute figures during a financial (calendar year) or a ceiling of the debt to GDP ratio;

e) curtailing payments when servicing the state debt while taking into account the ratio of such payments to incoming revenues from export operations (the acceptable size varies in the range of $20 \%$ to $25 \%$ ).

We should note a special role performed by the management order of foreign debt composition when introducing the indicative figures. We are talking about supporting a foreign debt structure that will be acceptable for a country from the point of view of existing interest, the payment period and the foreign currency structure.

According to Allen (2001) although the best foreign debt composition is individual for each country, international countries single out general principles of foreign debt management. In particular, debts are accounted for at commercial principles only 
after a maximal use of privileged (concessional) loans; repayment dates must be as close as possible to the dates of income collection from investment projects inside the country; the use of the method of foreign currency minimization when the rate of the national currency is unstable, etc.

According to Hjertholm (2003) the possibility that unforeseen expenses would appear, in particular, natural resources depletion, extensive social security spending, decrease in the number of employable population when creating the reserve funds of the country, migration, etc., should be taken into consideration. In this case, the minimum size of the reserves has to be adjusted by the sum of accumulated reserves in relation to deduction from profits into non-budget funds. For example, for the United States, the volume of accumulated reserves with pension funds must amount to no less than $100-150 \%$ of the sum deducted for social needs (Tversky et al., 1981). In New Zealand, a mid-term programme to reduce the volume of state foreign debt by $20 \%$ and to support the size of state industries at a corresponding level was accepted (Lopez, 2004).

According to Carvalho (2016) and Ravallion (2004) a strict sticking to financial rules in the country requires established support measures, including the legal basis, the implementation procedure (or at least, the mechanisms to push forward agreements) and independent control. At the same time, violation of budget and taxation policy rules entails introduction of fines, which can be of legal financial sanctions character, a public statement on undermined trust towards the violating country. At that, adoption of financial rules is linked to the order of setting a lower interest rate for the country (recipient). Such measures, of course, can improve the safety margin for the whole financial system of a state.

\section{Conclusion}

Debt management of international countries roots as a rule on a great reserve of produced capital, a developed system of economic and financial markets. The largest developed countries are at the same time the largest creditors and debtors in the international economy. At that, the character and specifics of foreign debt management in these countries is based on the following condition. State debt is fully securitized, i.e., there are no borrowings received from other creditors, including international financial organizations (which is typical of emerging countries) in its structure. State debt of developed countries is in fact a portfolio of issued and serviced debt securities with various durations, accessible for both residents and non-residents. In its turn, a wide number of operations can be applied to them depending on the goal, taking into account the current market situation (Christian, 2016). This is why the character of foreign debt management for developed countries is a way of regulating debt securities emission, which ensures the needs of budget financing with cheaper funding in the long term and attaining the risk and cost targets. The debt restructuring mechanisms are not used thanks to a 
virtual absence of non-payments on the government liabilities, excluding an early redemption of debt through the purchase of securities on the open market.

However, government debt servicing means a corresponding burden on the budget, which is a significant factor in all the processes of social and economic dynamics in the country. This is why one should understand the conditions, factors and consequences of state borrowing, their influence on the country's economy on different stages of its social and economic development clearly. Additional financial resources for the budget, which can be allocated for pressing matters of social and economic development are formed as a result of state borrowing (Kemal, 2001). Since maturity dates of the debt can be quite long, this process entails in its turn the need of working out and implementing a long-term monetary and credit policy.

Depending on the quality, scale and duration of debt instruments, which were issued at different dates, a positive as well as negative influence of a state debt increase on the dynamics of social and economic processes is possible. Consequently, it is important that a state finance manager have a methodology to analyze the interrelation of state debt liabilities forming and servicing on the one hand, and factors, which set the dynamics of social and economic development, on the other.

From the point of view of the balance of interest when carrying out the budget, debt and monetary and credit policies, debt managers, aides on budget and credit policies and the country's central bank management should have similar understanding of the goals of debt management, budget, debt and monetary and credit policies, because the different policy instruments that they use are mutually dependent.

At the same time the problems of state debt management are often caused by the absence of a strategy of prudent or safe debt management and deficiencies of poor macroeconomic regulation, as well as the absence of due cooperation between state bodies, which make decisions on state debt and control this sphere. Consequently, a further improvement of quantitative risk assessment methods based on achievements of the economic science and mathematics is becoming a hot reserve for improvement of foreign state debt management efficiency.

\section{References:}

Akaike, H. 1969. Fitting Autoregressive Models for Prediction. Annals of the Institute of Statistical Mathematics, 21, 243-247.

Akhmadeev, R.G. 2017. Taxation of End Consumption: Effect on Country Economies and its Characteristics. American Journal of Applied Sciences, 14(3), 381-391, DOI: 10.3844/ajassp.2017.381.391

Allen, R.C. 2001. The Great Divergence in European Wages and Prices from the Middle Ages to the First World War. Explorations in Economic History, 38, 411-447.

Arrow, K.J. 1974. General Economic Equilibrium: Purpose, Analytic Techniques Collective Choice, American Economic Review, 64, 253-272. 
Avramovic, D. 1964. Economic Growth and External debt. International Bank for Reconstruction and Development.

Brauers, W.K., Ginevičius, R. 2009. Robustness in regional development studies. The case of Lithuania. Journal of Business Economics and Management, 10(2), 121-140.

Carvalho, M., Leandro, S., Stephan, M. and Stephanie, W. 2016. Poverty and Economic Decision-Making: Evidence from Changes in Financial Resources at Payday: Dataset. American Economic Review, http://dx.doi.org/10.1257/aer.20140481.

Cerra, V., Rishi, M. and Saxena, S., 2008. Robbing the Riches: Capital Flight, Institutions and Debt. Journal of Development Studies, 44(8), 1190-1213.

Chen, S. and Ravallion, M. 1997. Household Welfare Impacts of China's Accession to the World Trade Organization. The World Bank, Policy Research Working Paper No. 3040.

Christian, K., Bernhard, W. 2016. The Commonalities of Global Crises: Markets, Communities and Nostalgia. Palgrave Macmillan UK, $371 \mathrm{p}$.

Hjertholm, P. 2003. Theoretical and empirical foundations of HIPC debt sustainability targets. Journal of Development Studies, 39 (6), 67-100.

Josef, C., Paul W. 2016. Global Banking Crises and Emerging Markets. Palgrave Macmillan UK, 313.

Kemal, A.R. 2001. Debt accumulation and its implications for growth and poverty. The Pakistan Development Review, 40(4), 263-281.

Kosov, M.E. 2016. Economic practicability substantiation of financial instrument choice. Journal of Applied Economic Sciences, 11(8), 1613-1623.

Kraay, A. 2006. When is growth pro-poor? Evidence from a panel of countries. Journal of Development Economics, 80(1), 198-227.

Lopez, J.H. 2004. Pro-Poor Growth: A Review of What we Know and of what we Don't. World Bank: 1-20, Available from: http://www. eldis.org/vfile/upload/1/document/0708/DOC17880.pdf.

Osipov, V.S. 2017. External Debt Burden and Its Impact on the Countries' Budgetary Policy. Journal of Applied Economic Sciences, 2(48), 342-355.

Phillips, P. and Loretan, M. 1991. Estimating Long Run Economic Equilibria. Review of Economic Studies, 58, 407-436, DOI:10.2307/2298004.

Ravallion, M. 2004. Pro-Poor Growth: A Primer, World Bank Policy Research Working Paper, 324.

Reinhart, C.M., Rogoff, K.S. 2004. Serial default and the 'paradox' of rich-to-poor capital flows. American Economic Review, 94, 53-58.

Reinhart, R., Carmen, M. and Kenneth, S.R. 2011. From Financial Crash to Debt Crisis. American Economic Review, 101(5), 1676-1706.

Stahl, D.O. 2013. Intertemporal Choice with Liquidity Constraints: Theory and Experiment. Economics Letters, 118(1), 101-103.

Thalassinos, I.E., Stamatopoulos, D.T. and Thalassinos, E.P. 2015. The European Sovereign Debt Crisis and the Role of Credit Swaps. Chapter book in The WSPC Handbook of Futures Markets (eds) W. T. Ziemba and A.G. Malliaris, in memory of Late Milton Miller (Nobel 1990) World Scientific Handbook in Financial Economic Series Vol. 5, Chapter 20, pp. 605-639, ISBN: 978-981-4566-91-9, (doi: 10.1142/9789814566926_0020).

Thalassinos, I.E., Pintea, M., Raţiu, I.P. 2015. The Recent Financial Crisis and Its Impact on the Performance Indicators of Selected Countries during the Crisis Period: A Reply. International Journal of Economics and Business Administration, 3(1), 3-20.

Tversky, Amos, and Kahneman 1981. The Framing of Decisions and the Psychology of Choice. Science, 211(4481), 453-458. 
Vashchekin, A.N., Khrustalev, M.M. 2005. Studying stability of the econometric model of nonantagonistic game of the wholesale market subjects. Automation and Remote Control, 10, 1677-1689.

World Bank. Various years. Global Development Finance.

World Bank. Various years. Quarterly External Debt Statistics.

Appendix A. Input Data to Support the Hypothesis on BRICS Countries

\begin{tabular}{|c|c|c|c|c|c|c|}
\hline Period & $\begin{array}{l}\text { Industrial } \\
\text { production } \\
\text { growth, \% }\end{array}$ & $\begin{array}{l}\text { Exports to } \\
\text { GDP ratio, \% }\end{array}$ & $\begin{array}{l}\text { Imports to } \\
\text { GDP ratio, \% }\end{array}$ & Inflation, $\%$ & $\begin{array}{l}\text { Unemployment, } \\
\%\end{array}$ & $\begin{array}{l}\text { State debt to } \\
\text { GDP ratio, \% }\end{array}$ \\
\hline \multicolumn{7}{|l|}{ China } \\
\hline 2006 & 22,9 & 27,73 & 23,29 & 1,5 & 4,1 & 16,2 \\
\hline 2007 & 13,4 & 27,87 & 22,26 & 4,8 & 4 & 19,6 \\
\hline 2008 & 9,3 & 31,75 & 19,12 & 5,9 & 4,2 & 17 \\
\hline 2009 & 9,9 & 24,13 & 22,57 & $-0,7$ & 4,3 & 17,7 \\
\hline 2010 & 11 & 26,84 & 24,91 & 3,2 & 4,1 & 43,5 \\
\hline 2011 & 13 & 27,17 & 24,91 & 5,4 & 6,5 & 38,5 \\
\hline 2012 & 7,9 & 22,04 & 22,02 & 2,6 & 6,5 & 26,1 \\
\hline 2013 & 7,7 & 24,72 & 21,80 & 2,6 & 4,1 & 22,4 \\
\hline 2014 & 7,3 & 21,66 & 17,45 & 2 & 4,1 & 14,9 \\
\hline 2015 & 7 & 19,95 & 14,02 & 1,5 & 4,2 & 16,7 \\
\hline \multicolumn{7}{|l|}{ India } \\
\hline 2006 & 7,5 & 8,39 & 12,45 & 5,3 & 7,8 & 75,4 \\
\hline 2007 & 8,5 & 9,72 & 16,30 & 6,4 & 7,2 & 72,7 \\
\hline 2008 & 4,8 & 14,10 & 24,41 & 8,3 & 6,8 & 73,1 \\
\hline 2009 & 9,3 & 13,30 & 21,69 & 10,9 & 10,7 & 69,4 \\
\hline 2010 & 9,7 & 13,82 & 21,92 & 12 & 10 & 50,6 \\
\hline 2011 & 4,8 & 16,55 & 26,59 & 8,9 & 9,8 & 50,5 \\
\hline 2012 & 0 & 18,19 & 25,86 & 9,7 & 8,5 & 51,7 \\
\hline 2013 & 0,9 & 18,19 & 27,43 & 10 & 9,1 & 51,4 \\
\hline 2014 & 3,8 & 16,09 & 23,09 & 6,7 & 7,3 & 51,7 \\
\hline 2015 & 2,8 & 13,17 & 19,80 & 5,6 & 7,1 & 51,7 \\
\hline \multicolumn{7}{|l|}{ Brasil } \\
\hline 2006 & 3,2 & 10,53 & 7,13 & 4,2 & 10 & 66,7 \\
\hline 2007 & 4,9 & 9,98 & 6,63 & 3,6 & 9,3 & 65,2 \\
\hline 2008 & 4,3 & 11,96 & 10,46 & 5,7 & 7,9 & 63,6 \\
\hline 2009 & $-5,5$ & 9,56 & 7,98 & 4,9 & 8,1 & 68,1 \\
\hline 2010 & 11,5 & 9,66 & 8,69 & 5 & 6,7 & 54,7 \\
\hline 2011 & 4 & 10,17 & 8,98 & 6,6 & 6 & 54,2 \\
\hline 2012 & $-0,3$ & 10,00 & 9,20 & 5,4 & 5,5 & 58,8 \\
\hline 2013 & 3 & 11,05 & 10,94 & 5,9 & 5,4 & 56,7 \\
\hline 2014 & $-1,5$ & 10,03 & 10,21 & 6,3 & 4,8 & 58,9 \\
\hline 2015 & -5 & 10,51 & 9,68 & 10,6 & 6,4 & 67,3 \\
\hline \multicolumn{7}{|l|}{ Russia } \\
\hline 2006 & 4,8 & 32,08 & 17,32 & 9,7 & 7,2 & 9 \\
\hline 2007 & 7,4 & 27,35 & 17,19 & 9 & 6,1 & 8,5 \\
\hline 2008 & 3,5 & 28,40 & 18,18 & 14,1 & 6,4 & 7,9 \\
\hline 2009 & $-13,1$ & 24,83 & 15,70 & 11,7 & 8,4 & 11 \\
\hline
\end{tabular}




\begin{tabular}{lllllll}
\hline 2010 & 8,3 & 27,06 & 16,81 & 6,9 & 7,5 & 7,9 \\
2011 & 5 & 27,69 & 17,18 & 8,4 & 6,6 & 8,3 \\
2012 & 2,6 & 27,02 & 17,18 & 5,1 & 5,5 & 8 \\
2013 & 0,1 & 24,96 & 14,91 & 6,8 & 5,5 & 8,1 \\
2014 & 0,6 & 24,20 & 14,97 & 7,8 & 5,2 & 10,4 \\
2015 & $-3,5$ & 27,33 & 15,96 & 15,4 & 5,4 & 13,5 \\
\multicolumn{2}{l}{ South Africa } & & & & & \\
2006 & 7,1 & 19,49 & 20,29 & 4,7 & 25,5 & 31,4 \\
2007 & 4,4 & 20,71 & 21,52 & 7,9 & 22,2 & 27,4 \\
2008 & 1 & 31,24 & 32,87 & 11,5 & 22,9 & 26,8 \\
2009 & $-7,2$ & 23,42 & 23,24 & 7,1 & 23,9 & 30,9 \\
2010 & 3 & 23,56 & 22,52 & 4,1 & 24,9 & 33,4 \\
2011 & 2,5 & 24,38 & 23,79 & 5 & 24,9 & 38,6 \\
2012 & 0 & 23,92 & 26,25 & 5,7 & 25,1 & 42,3 \\
2013 & 0,9 & 26,90 & 29,05 & 5,8 & 24,7 & 46,1 \\
2014 & 2 & 27,11 & 28,99 & 6,1 & 25,1 & 44,8 \\
2015 & 1,7 & 26,82 & 27,36 & 4,8 & 25,9 & 45,4 \\
\hline
\end{tabular}

Appendix B. Analytical Calculations of the Hypothesis on BRICS Countries

\begin{tabular}{llll}
\hline China & & $\mathrm{t}$ Stat & P-value \\
\hline Determination coefficient, R2 & 0,668164413 & & \\
Value of Fisher function, F & 1,208124336 & & \\
Free variable ßok & 7,834861066 & 0,178921 & 0,869401 \\
Industrial production growth, B1k & $-0,31400902$ & $-0,1343$ & 0,901668 \\
Exports to GDP ratio, B2k & $-174,803939$ & $-0,84951$ & 0,458014 \\
Imports to GDP ratio, B3k & 280,9447469 & 1,616475 & 0,204412 \\
Inflation, B4k & 2,986519786 & 0,906933 & 0,431302 \\
Unemployment, B5k & $-1,05764136$ & $-0,22225$ & 0,838393 \\
Brasil & & & \\
Determination coefficient, R2 & 0,942438604 & & \\
Value of Fisher function, F & 9,823652698 & & \\
Free variable Bok & 32,56847487 & 2,934449 & 0,060782 \\
Industrial production growth, B1k & $-0,641014$ & $-3,85949$ & 0,030743 \\
Exports to GDP ratio, B2k & $-116,002535$ & $-0,43522$ & 0,692813 \\
Imports to GDP ratio, B3k & 151,0151572 & 0,721735 & 0,522624 \\
Inflation, B4k & 0,416278361 & 0,825179 & 0,469765 \\
Unemployment, B5k & 3,736139112 & 2,62059 & 0,078961 \\
India & & & \\
Determination coefficient, R2 & 0,669187412 & & \\
Value of Fisher function, F & 1,213715747 & & \\
Free variable ok & 100,3953009 & 2,3771 & 0,097874 \\
Industrial production growth, B1k & $-0,86454412$ & $-0,31035$ & 0,776607 \\
Exports to GDP ratio, B2k & $-760,332555$ & $-1,41592$ & 0,251764 \\
Imports to GDP ratio, B3k & 337,9266967 & 1,141273 & 0,336606 \\
Inflation, B4k & 1,760264001 & 0,522529 & 0,637435 \\
Unemployment, B5k & $-2,19631399$ & $-0,45149$ & 0,682276 \\
Russia & & & \\
Determination coefficient, R2 & 0,781894359 & & \\
Value of Fisher function, F & 2,15096048 & & \\
Free variable Bok & 11,84568606 & 0,791139 & 0,486641 \\
\hline
\end{tabular}


Macroeconomic Indicators and their Impact on the Foreign Debt Burden: The Case of BRICS Countries

82

\begin{tabular}{llll}
\hline Industrial production growth, ß1k & $-0,11861556$ & $-0,77278$ & 0,495953 \\
Exports to GDP ratio, ß2k & 77,77752734 & 0,688315 & 0,540704 \\
Imports to GDP ratio, B3k & $-146,391872$ & $-1,13185$ & 0,339993 \\
Inflation, ß4k & 0,236069222 & 0,961556 & 0,407206 \\
Unemployment, B5k & $-0,19114421$ & $-0,32114$ & 0,769178 \\
South Africa & & & \\
Determination coefficient, R2 & 0,945705084 & & \\
Value of Fisher function, F & 10,45075835 & & \\
Free variable ßok & 13,80872409 & 0,158582 & 0,884072 \\
Industrial production growth, ß1k & $-0,10614898$ & $-0,26625$ & 0,807299 \\
Exports to GDP ratio, B2k & $-264,287042$ & $-2,11563$ & 0,124699 \\
Imports to GDP ratio, B3k & 350,7315258 & 3,355887 & 0,043867 \\
Inflation, ß4k & $-3,20500191$ & $-1,36368$ & 0,265977 \\
Unemployment, B5k & 0,795523297 & 0,205735 & 0,850168 \\
\hline
\end{tabular}

